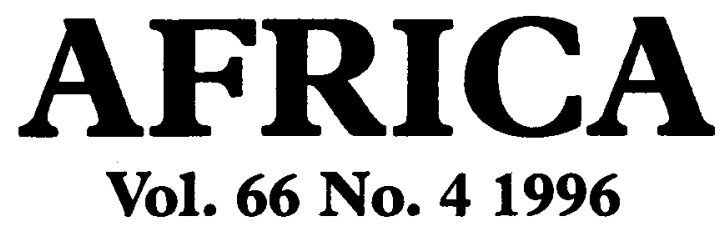

\author{
Editor $\cdot$ Rédacteur \\ Murray Last \\ Reviezws editor $\cdot$ Rédacteur comptes-rendus \\ Tom Young \\ Consultant editors - Rédacteurs consultatifs \\ Kwame Arhin - Bolanle Awe - Caroline Bledsoe - Angela Cheater \\ Calestous Juma - Paul Sinclair - Nicole Sindzingre - Ulrike Wanizek
}

Imagining democracy: political culture and democratisation in Buganda - Mikael Karlström

Defining Akyemfo: the construction of citizenship in Akyem Abuakwa, Ghana, 1700-1939 - Richard Rathbone

Inculcation of ideology among the Sidāma of Ethiopia • fohn H. Hamer

\title{
Refashioning modernity
}

The domestication of modernity: different trajectories $\cdot$ Peter Geschiere and

Michael Rowlands

'Pillaging Jesus': healing churches and the villagisation of Kinshasa - René Devisch 555

Post-socialist micro-politics: Kilimanjaro, 1993 - Sally Falk Moore

\section{Review article}

The politicisation of religion in Nigeria: three studies • f. D. Y. Peel

\section{Reviews of books}

Elliot Fratkin, Kathleen A. Galvin and Eric Abella Roth (eds.), African Pastoralist Systems (MARIO I. AGUIIAR); Jonathan Baker and Tade Akin Aina (eds.), The Migration Experience in Africa (ANTHONY o'CONNOR); Eno Blankson Ikpe, Food and Society in Nigeria (BARRIE SHARPE); Ruth Iyob, The Eritrean Struggle for Independence, and Ali Couba, Djibouti: une nation en otage (DAVID STYAN); Aline Tauzin, Contes arabes de Mauritanie (MICHELINE GALLEY); Kwame Bediako, Christianity in Africa (PAUL GIFFORD); Irving Hexham (ed.), The Scriptures of the amaNazaretha of EKuphaKameni (AXEL-IVAR BERGLUND); Phillip Chiviges Naylor and Alf Andrew Heggoy, Historical Dictionary of Algeria, and Anthony G. Pazzanita and Tony Hodges, Historical Dictionary of Western Sahara (CLARE SPENCER); C. Crosby, Historical Dictionary of Malawi (DEBORAH POTTS); Percy Turner Wilde, Bwana Polisi (DAVD M. ANDERSON); Ngwabi Bhebe and Terence Ranger (eds.), Soldiers in Zimbabwe's Liberation War 


\section{Contents continued}

(ERIC T. YOUNG); P. Gibbon (ed.), Liberalised Development in Tanzania (TIM KELSALL); Petr Zima, Lexique dendi (GERRT J. DIMMENDAAL); Philip Baker (ed.), International Directory of African Sudic Research (GRAHAM FURNISS)

General index to volume 66 


\section{CONTRIBUTORS}

RENE DEVISCH is Professor of Social Anthropology at the Catholic Universities of Leuven and Louvain-Belgium, and is a member of the Belgian School of Psychoanalysis. His most recent book on the Yaka of Zaire, Weaving the Threads of Life, was published in 1993 and complements his 1992 film with Dirk Dumon, The Oracle of Maama Tseembu.

PETER GESCHIERE is Professor of Social Anthropology, University of Leiden. He has published extensively on Cameroon, in particular on the Maka. In 1994 he published Sorcellerie et politique en Afrique (forthcoming in English as The Modernity of Witchcraft).

JOHN HAMER teaches anthropology at the University of the South, at Sewanee, Tennessee. He has been publishing on the Sidama for the last thirty years.

MIKAEL KARLSTROM is currently completing a doctoral thesis in anthropology for the University of Chicago.

SALLY FALK MOORE teaches anthropology at Harvard University. Her most recent book on the Chagga of Tanzania is Social Facts and Fabrications (1986); in 1995 she published Anthropology and Africa.

J. D. Y. PEEL is Professor of Anthropology and Sociology with reference to Africa in the University of London at the School of Oriental and African Studies. He is author of Aladura (1968) and Ijeshas and Nigerians (1983).

RICHARD RATHBONE is Professor of Modern African History at the School of Oriental and African Studies, London. In 1993 he published Murder and Politics in Colonial Ghana and, in 1992, two volumes on the transfer of power in Ghana.

MICHAEL ROWLANDS is Professor of Anthropology at University College London. He has done extensive fieldwork in West Cameroon and specialises in the analysis of material culture. In 1993 he edited Dominance and Resistance. 